\title{
PENGARUH FAKTOR PERILAKU TERHADAP PENGGUNAAN JAMBAN CEMPLUNG
}

\author{
Khairani Murni ${ }^{1^{*}}$, Mappeaty Nyorong ${ }^{2}$, Anto $^{3}$ \\ 1,2,3 IImu Kesehatan Masyarakat, Institut Kesehatan Helvetia \\ *Email: airanimurni@gmail.com
}

\begin{abstract}
ABSTRAK
Jamban yang tidak sehat dapat membawa efek terhadap penurunan tingkat kesehatan Berdasarkan data Dinas Kesehatan Kabupaten Labuhan Batu Selatan tahun 2019, di ketahui bahwa cakupan PHBS di kabupaten Labuhan Batu Selatan untuk ketersediaan jamban sehat hanya sebesar 52,7\%, adapun tujuan peneitian ini adalah untuk menganalisis Pengaruh Faktor perilaku terhadap penggunaan jamban cemplung di desa sisumut kecamatan kota Pinang Kabupaten Labuhan Batu Selatan.Penelitian ini menggunakan jenis penelitian kuantitatif dengan rancangan cross sectional study. Lokasi penelitian ini dilakukan di desa Sisumut kecamatan Kota Pinang Kabupaten Labuhan Batu Selatan. Waktu Penelitian berlangsung mulai bulan September sampai dengan oktober 2019.Populasi penelitian yaitu seluruh kepala keluarga di desa Sisumut kecamatan Kota Pinang Kabupaten Labuhan Batu Selatan dengan jumlah sebanyak 290 kepala keluarga.Teknik yang digunakan adalah purposive sampling berjumlah 37 orang. Data hasil survey dianalisis dengan menggunakan uji Chi Square dan regresi logistik.Berdasarkan hasil penelitian diketahui bahwa, pengetahuan $(p=0,000)$, sikap $(p=0,000)$, ketersediaan akses $(p=0,000)$ berpengaruh terhadap penggunaan jamban cemplung di Desa Sisumut Kecamatan Kota Pinang Kabupaten Labuhan Batu Selatan.Berdasarkan hasil penelitian, dapat disimpulkan bahwa pengetahuan, sikap dan ketersediaan akses berpengaruh terhadap penggunaan jamban cemplung di Desa Sisumut Kecamatan Kota Pinang Kabupaten Labuhan Batu Selatan, Sehingga adapun saran dalam penelitian ini diharapkan agar membuat program penyuluhan tentang pemanfaatan jamban cemplung kepada masyarakat.
\end{abstract}

Kata kunci: Pengetahuan,sikap, perilaku, jamban cemplung

\begin{abstract}
Unhealthy latrines can have an effect on reducing the level of health. Based on data from the Labuhan Batu Selatan District Health Office in 2019, it was found that the PHBS coverage in Labuhan Batu Selatan district for the availability of healthy latrines was only $52.7 \%$, while the aim of this study was to analyze the influence of behavioral factors on the use of pit latrines in Sisumut village, Pinang city, Labuhan Batu Selatan Regency. This research uses quantitative research with cross sectional study design. This research was conducted from September to October 2019. The study population was all family heads in the village with a total of 290 households. The technique used was purposive sampling totaling 37 people. Survey data were analyzed using the Chi Square test and logistic regression. Results showed that knowledge $(p=0,000)$, attitude $(p=0,000)$, availability of access $(p=0,000)$ affect the use of pit latrine.Thus, it can be concluded that knowledge, attitude and availability of access affect the use of pit latrines, so that the suggestion in this study is expected to create a counseling program about the use of pit latrines to the community.
\end{abstract}

Keyword: Knowledge.attitude, behavior, pit latrines

\section{PENDAHULUAN}

Salah satu indikator PBHS adalah tersedianya jamban yang memenuhi syarat kesehatan dan dapat menghindarkan lingkungan dari penyebaran penyakit.Merujuk Kementerian Kesehatan RI tahun 2018, jamban sehat adalah jamban yang tidak mencemari lingkungan, tak ada serangga yang keluar masuk, tidak menimbulkan bau, dan lubang jamban terkontruksi dengan baik serta tidak menimbulkan kecelakaan. Jamban yang tidak sehat dapat membawa efek terhadap penurunan tingkat kesehatan. ${ }^{1}$ Berdasarkan data World Health Organization tahun 2018, diperkirakan sebanyak 2,4 miliar atau 1 dari 3 penduduk dunia tidak memiliki jamban di rumah, dan kurang dari 1 miliar penduduk masih buang air besar di tempat terbuka. Hal tersebut mengakibatkan penyebaran penyakit, seperti diare, penyakit kulit dan malagizi. WHO juga mencatat bahwa selama tahun 2018 lebih dari 340.000 anak-anak di bawah lima tahun meninggal akibat sanitasi dan air yang tidak higienis yang disebabkan oleh jamban terbuka. Pada tahun 2018, terdapat 4,5 miliar orang hidup tanpa sanitasi yang dikelola dengan aman dan 2,1 miliar orang tidak memiliki jamban dan kekurangan akses ke tempat air bersih. ${ }^{2}$ 
Data Dinas Kesehatan Provinsi Sumatera Utara tahun 2019 menunjukkan bahwa, pada tahun 2016 tempat pembuangan tinja pada tangki septik sekitar 74,08 \%, tahun 2017 sekitar $83,69 \%$ dan tahun 2018 sekitar 90,61\%. Berdasarkan hal tersebut, adapun hal yang perlu dicermati adalah masih adanya rumah tangga yang tempat pembuangan tinja selain pada tangki septik atau dengan kata lain, masih banyak masyarakat ditemukan buang air besar di area terbuka seperti di pekarangan, parit, di sungai, di kolam yaitu sebesar $33,4 \%$. Adapun Kabupaten yang masyarakatnya paling banyak menggunakan pekarangan, parit, sungai dan kolam sebagai tempat buang air besar adalah Kabupaten Labuhan Batu Selatan. ${ }^{3}$

Berdasarkan data Dinas Kesehatan Kabupaten Labuhan Batu Selatan tahun 2019, di ketahui bahwa cakupan PHBS di kabupaten Labuhan Batu Selatan untuk ketersediaan jamban sehat hanya sebesar $52,7 \%$, selain itu masyarakat menggunakan sungai sebagai tempat buang air besar. Hal tersebut menunjukkan bahwa rendahnya keperdulian masyarakat tentang ketersediaan jamban dan manfaat jamban, padahal dengan perilaku masyarakat buang air besar sembarangan dapat berbagi penyakit, seperti diare dan penyakit kulit. $^{4}$

Salah satu kecamatan di Kabupaten Labuhan Batu Selatan yang paling banyak menggunakan sungai sebagai jamban adalah kecamatan Kota Pinang. Berdasarkan hasil observasi di Puskesmas Kecamatan Kota Pinang Kabupaten Labuhan Batu Selatan, diperoleh data diare yang disebabkan penggunaan jamban sembarangan selama 5 tahun terakhir, yaitu sebagai berikut: Pada tahun 2015 angka kejadian diare mencapai 221 kejadian, pada tahun 2016 meningkat menjadi 450 kejadian, sedangkan pada tahun 2017 angka kejadian diare menurun hingga mencapai 199 kejadian, namun pada tahun 2018 kembali meningkat hingga mencapai 330 kejadian. Tingginya angka kejadian diare tersebut tentu saja dapat berakibat buruk bagi kesehatan masyarakat itu sendiri, dan disebabkan oleh rendahnya kepemilikan jamban di Kecamatan Kota Pinang Kabupaten Labuhan Batu Selatan.

Berdasarkan survey awal yang dilakukan di Kecamatan Kota Pinang Kabupaten Labuhan Batu Selatan dengan melakukan wawancara terhadap 10 orang kepala keluarga, diketahui bahwa dari 10 orang kepala keluarga terdapat 8 orang kepala keluarga mengaku tidak memiliki jamban di rumah dan lebih sering menggunakan fasilitas umum jamban cemplung, sedangkan 2 orang lainnya memiliki jamban leher angsa di rumah. Adapun alasan kepala keluarga tidak menyediakan jamban leher angsa di rumah adalah 1) tidak mengetahui manfaat jamban, 2) sudah menjadi kebiasaan menggunakan sungai sebagai jamban, 3) rumah dekat dengan sungai, 4) tidak memiliki dana untuk membangun jamban. Berdasarkan paparan di atas, adapun yang menjadi tujuan dalam penelitian ini adalah untuk menganalisis pengaruh faktor perilaku terhadap penggunaan jamban cemplung di desa Sisumut Kecamatan Kota Pinang Kabupaten Labuhan Batu Selatan.

\section{BAHAN DAN METODE}

Lokasi penelitian ini dilakukan di desa Sisumut kecamatan Kota Pinang Kabupaten Labuhan Batu Selatan. Waktu Penelitian berlangsung mulai bulan September sampai dengan oktober 2019.

Populasi penelitian yaitu seluruh kepala keluarga di desa Sisumut kecamatan Kota Pinang Kabupaten Labuhan Batu Selatan dengan jumlah sebanyak 290 kepala keluarga.Teknik yang digunakan adalah purposive sampling berjumlah 37 orang.Data hasil survey dianalisis dengan menggunakan uji Chi Square dan regresi logistik.

\section{HASIL}

\section{Analisis Data Univariat}

Berdasarkan data yang diperoleh dari hasil penelitian dengan 37 responden dapat dilihat dalam tabel distribusi frekuensi sebagai berikut.

Tabel 1.Distribusi Karakteristik Responden Berdasarkan Umur, Pendidikan, Pekerjaan

\begin{tabular}{ccc}
\hline Umur & $\mathbf{n}$ & Persentase \\
\hline 21-25 Tahun & 3 & 8,11 \\
26-35 Tahun & 7 & 18,92 \\
36-45 Tahun & 11 & 29,73 \\
46-55 Tahun & 9 & 24,32 \\
56-65 Tahun & 7 & 18,92 \\
\hline Pendidikan & $\mathbf{n}$ & Persentase \\
\hline SD & 5 & 13,51
\end{tabular}




\begin{tabular}{ccc} 
SMP & 9 & 24,32 \\
SMA & 15 & 40,54 \\
PT & 8 & 21,62 \\
\hline Pekerjaan & $\mathbf{n}$ & Persentase \\
\hline Petani & 16 & 43,24 \\
Wiraswasta & 12 & 32,43 \\
PNS & 9 & 24,33 \\
\hline Jumlah & $\mathbf{3 7}$ & $\mathbf{1 0 0}$ \\
\hline
\end{tabular}

Berdasarkan tabel 1 di atas, diketahui bahwa dari 37 responden, sebagian besar responden berumur 36-45 tahun yaitu sebanyak $11(29,73 \%)$ responden, sedangkan responden lainnya berumur 21-25 tahun yaitu sebanyak 3 $(8,11 \%)$ responden, umur $26-35$ tahun sebanyak 7 $(18,92)$, umur $46-55$ tahun sebanyak 9 (24,32\%), umur 56-65 tahun 7 (18,92\%) responden.

Dari 37 responden diketahui bahwa sebagian besar responden merupakan tamatan SMA yaitu sebanyak 15 (40,54\%) responden, tamatan SD sebanyak $5(13,51)$ tamatan SMP sebanyak $9(24,32 \%)$ responden dan tamatan PT ada sebanyak $8(2,62 \%)$ responden

\section{Analisis Data Bivariat}

Untuk mengetahuipengaruh faktor perilaku terhadap penggunaan jamban cemplung di Desa Sisumut Kecamatan Kota Pinang Kabupaten Labuhan Batu Selatan, dapat dilihat pada tabel dibawah ini:

Tabel 2.Faktor Perilaku Terhadap Penggunaan Jamban Cemplung di Desa Sisumut Kecamatan Kota Pinang Kabupaten Labuhan Batu Selatan

\begin{tabular}{|c|c|c|c|c|c|c|c|}
\hline \multirow{3}{*}{ Pengetahuan } & \multicolumn{6}{|c|}{ Penggunaan Jamban Cemplung } & \multirow[b]{2}{*}{ p value } \\
\hline & \multicolumn{2}{|c|}{ Dimanfaatkan } & \multicolumn{2}{|c|}{ Tidak Dimanfaatkan } & \multicolumn{2}{|c|}{ Jumlah } & \\
\hline & $\mathrm{n}$ & Persentase & $\mathrm{n}$ & Persentase & $\mathrm{n}$ & Persentase & \multirow{4}{*}{0,000} \\
\hline Baik & 14 & 37,83 & 4 & 10,81 & 18 & 48,65 & \\
\hline Kurang & 3 & 8,11 & 16 & 43,24 & 19 & 51,35 & \\
\hline Jumlah & 17 & 45,95 & 20 & 54,05 & 37 & 100 & \\
\hline \multirow{3}{*}{ Sikap } & \multicolumn{6}{|c|}{ Penggunaan Jamban Cemplung } & \multirow{2}{*}{ p value } \\
\hline & \multicolumn{2}{|c|}{ Dimanfaatkan } & \multicolumn{2}{|c|}{ Tidak Dimanfaatkan } & \multicolumn{2}{|c|}{ Jumlah } & \\
\hline & $\mathrm{n}$ & Persentase & $\mathrm{n}$ & Persentase & $\mathrm{n}$ & Persentase & \multirow{4}{*}{0,000} \\
\hline Positif & 10 & 27,03 & 1 & 2,70 & 11 & 29,73 & \\
\hline Negatif & 7 & 18,92 & 19 & 51,35 & 26 & 70,27 & \\
\hline Jumlah & 17 & 45,95 & 20 & 54,05 & 37 & 100 & \\
\hline \multirow{3}{*}{ Ketersediaan Akses } & \multicolumn{6}{|c|}{ Penggunaan Jamban Cemplung } & \multirow{2}{*}{ p value } \\
\hline & \multicolumn{2}{|c|}{ Dimanfaatkan } & \multicolumn{2}{|c|}{ Tidak Dimanfaatkan } & \multicolumn{2}{|c|}{ Jumlah } & \\
\hline & $\mathrm{n}$ & Persentase & $\mathrm{n}$ & Persentase & $\mathrm{n}$ & Persentase & \multirow{4}{*}{0,000} \\
\hline Tersedia & 15 & 40,54 & 4 & 10,81 & 19 & 51,35 & \\
\hline Tidak Tersedia & 2 & 5,41 & 16 & 43,24 & 18 & 48,65 & \\
\hline Jumlah & 17 & 45,95 & 20 & 54,05 & 37 & 100 & \\
\hline
\end{tabular}

Berdasarkan tabel 2 diketahui bahwa dari 37 responden yang diteliti, sebagian besar responden memiliki pengetahuan kurang sebanyak 19 (51,35\%) responden. Dari 19 $(51,35 \%)$ responden tersebut, ada sebanyak 3 $(8,11 \%)$ responden memiliki pengetahuan kurang dan memanfaatkan jamban cemplung, dan sebanyak 16 (43,24\%) responden memiliki pengetahuan kurang dan tidak memanfaatkan jamban cemplung. Berdasarkan hasil perhitungan uji statistik diperoleh nilai $p$ significancy yaitu $0,000<0,05$, sehingga dapat disimpulkan bahwa ada pengaruh pengetahuan terhadap penggunaan jamban cemplung di Desa
Sisumut Kecamatan Kota Pinang Kabupaten Labuhan Batu Selatan.

Berdasarkan tabel juga diketahui bahwa dari 37 responden yang diteliti, sebagian besar responden memiliki sikap negtif sebanyak 26 $(70,27 \%)$ responden. Dari $26 \quad(70,27 \%)$ responden tersebut, ada sebanyak 7 (18,92\%) responden memiliki sikap negatif dan memanfaatkan jamban cemplung, dan sebanyak $19(51,35 \%)$ responden memiliki sikap negatif dan tidak memanfaatkan jamban cemplung. Berdasarkan hasil perhitungan uji statistik diperoleh nilai $p$ significancy yaitu $0,000<0,05$, sehingga dapat disimpulkan bahwa ada pengaruh sikap terhadap penggunaan jamban 
cemplung di Desa Sisumut Kecamatan Kota Pinang Kabupaten Labuhan Batu Selatan.

Berdasarkan tabel diketahui bahwa dari 37 responden yang diteliti, sebagian besar responden tersedia akses sebanyak 19 (51,35\%) responden. Dari $19 \quad(51,35 \%)$ responden tersebut, ada sebanyak $3(8,11 \%)$ responden tersedia akses dan memanfaatkan jamban cemplung, dan sebanyak 16 (43,24\%) responden tersedia akses dan tidak memanfaatkan jamban cemplung. Berdasarkan hasil perhitungan uji statistik diperoleh nilai $p$ significancy yaitu $0,000<0,05$, sehingga dapat disimpulkan bahwa ada pengaruh ketersediaan akses terhadap penggunaan jamban cemplung di Desa Sisumut Kecamatan Kota Pinang Kabupaten Labuhan Batu Selatan

\section{Analisis Multivariat}

Adapun faktor perilaku yang paling berpengaruh terhadap penggunaan jamban cemplung di Desa Sisumut Kecamatan Kota Pinang Kabupaten Labuhan Batu Selatan, adalah sbagai berikut

\begin{tabular}{ccccc}
\multicolumn{2}{c}{ Tabel 3.Analisis MultivariatTerhadap Penggunaan Jamban Cemplung Di Desa Sisumut } \\
& Kecamatan Kota Pinang Kabupaten Labuhan Batu Selatan \\
\hline ariabel & B & P vlue & Exp(B)OR & 95\%Cl for Exp(B) \\
\hline tahuan & 2,900 & 0,005 & 14,686 & $1,962-99,477$ \\
ediaan & 2,602 & 0,011 & 13,494 & $1,833-80,313$
\end{tabular}

Berdasarkan tabel 3diatas dapat dilihat bahwa analisis regresi logistik menghasilkan satu variabel yang paling dominan berpengaruh terhadap terhadap penggunaan jamban cemplung di Desa Sisumut Kecamatan Kota Pinang Kabupaten Labuhan Batu Selatan dengan $p$ value $<0,05$, yaitu variabel pengetahuan dengan signifikan 0,005 ( $p$ value $<0,05), \mathrm{OR}=14,686(95 \% \mathrm{Cl}=1,962-$ 99,477 ) artinya responden yang memiliki pengetahuan kurang mempunyai peluang 14,686 kali untuk tidak memanfaatkan jamban cemplung di Desa Sisumut Kecamatan Kota Pinang Kabupaten Labuhan Batu Selatan dibandingkan dengan responden yang memiliki pengetahuan yang baik dengan nilai koefisien $B$ yaitu 2,817 bernilai positif, maka semakin kurang pengetahuan maka semakin banyak responden yang tidak memanfaatkan jamban cemplung di Desa Sisumut Kecamatan Kota Pinang Kabupaten Labuhan Batu Selatan.

\section{PEMBAHASAN}

Berdasarkan hasil penelitian dari 37 responden yang diteliti, sebagian besar responden memiliki pengetahuan kurang sebanyak 19 (51,35\%) responden. Dari 19 $(51,35 \%)$ responden tersebut, ada sebanyak 3 $(8,11 \%)$ responden memiliki pengetahuan kurang dan memanfaatkan jamban cemplung, dan sebanyak $16(43,24 \%)$ responden memiliki pengetahuan kurang dan tidak memanfaatkan jamban cemplung. Berdasarkan hasil perhitungan uji statistik diperoleh nilai $p$ significancy yaitu $0,000<0,05$, sehingga dapat disimpulkan bahwa ada pengaruh pengetahuan terhadap penggunaan jamban cemplung di Desa Sisumut Kecamatan Kota Pinang Kabupaten Labuhan Batu Selatan.

Pengetahuan yang rendah memungkinkan tidak adanya tindakan yang positif tentang perilaku pemanfaatan jamban,semakin rendah pengetahuan seseorang mengenai jamban, maka semakin rendah pula pemanfaatan jamban. Erlinawati menyebutkan bahwa variabel pengetahuan tentang jamban merupakan variabel confounder terhadap hubungan pendidikan dengan perilaku keluarga terhadap penggunaan jamban. Penjelasannya karena yang memliki pengetahuan tinggi tentang jamban pada umumnya adalah orang yang berpendidikan tinggi. Hal ini disebabkan karena orang yang berpendidikan tinggi lebih mudah memahami (comprehension) dan mudah menerapkan (application) secara benar objek yang diketahui pada kehidupan sehari hari. ${ }^{5}$

Hasil penelitian ini sejalan dengan teori Notoadmojo yang menyatakan bahwa pengetahuan merupakan merupakan faktor penting dalam upaya peningkatan pengelolaan jamban keluarga, karena dengan baiknya pengetahuan maka semakin memahami dan mampu melaksanakan upaya pengelolaan jamban keluarga yang baik, baik dalam pemeliharaan, pemeliharaan jamban jika rusak atau tersumbat serta menjaga kebersihan jamban dari berbahai kotoran, sehingga lingkungan tempat tinggal bersih dan sehat dan dapat mencegah terjadinya pencemaran lingkungan. Pengetahuan seseorang didapatkan dari pengalaman dan informasi yang didapatkan, baik melalui pelatihan, bimbingan, pembinaan 
maupun melalui pengamatan, sehingga dapat memberikan tanggapan atau respon terhadap apa yang diamati. ${ }^{6}$

Maraknya masyarakat yang $B A B$ di sungai dan tidak memanfaatkan jamban cemplung di Desa Sisumut Kecamatan Kota Pinang Kabupaten Labuhan Batu Selata salah satunya juga dikarenakan tidak adanya kemauan dari kepala keluarga untuk belajar mencari tahu sesuatu yang belum diketahui. Sebagian besar responden bekerja sebagai petani yang setiap sore mereka pergi bersawah dan kembali sore hari, pagi hari mereka gunakan untuk memasak dan mencuci, begitu seterusnya kehidupan yang mereka jalani sehingga menurut mereka tidak ada waktu bagi kepala keluarga untuk mencari tahu fungsi pemanfaatan jamban, atau masyarakat sudah tau akan pentingnya pemanfaatan jamban namun hanya sebatas tahu, belum mampu untuk melaksanakan.

Sesuai dengan hasil penelitian Ibrahim, dkkyang menyebutkan terdapat hubungan antara pengetahuan dengan pemanfaatan jamban $(p=0,000)$ di Padangsidimpuan Angkola Jalu. Peneliti menganggap promosi untuk memanfaatkan jamban seharusnya dilakukan secara optimal sebagai upaya dalam rangka menggerakkan dan memberdayakan masyarakat yaitu melalui pemberian informasi secara terus menerus dan berkesinambungan mengikuti perkembangan sasaran, yang diharapkan sasaran (responden) tersebut berubah dari tidak tahu menjadi tahu, sadar dari tahu menjadi mau dan dari mau menjadi mampu melaksanakan perilaku yang diperkenalkan. ${ }^{7}$

Masyarakat yang tidak memiliki jamban pribadi, dan tidak mau menggunakan sarana jamban cemplung untuk kebutuhan buang air besar (BAB) atau menumpang ke saudara dan tetangga untuk $B A B$ adalah masyarakat yang sudah merasa nyaman dengan $B A B$ di sungai, mereka menyatakan bahwa jamban cemplung itu sempit dan tidak ada air yang bersih, mereka malas mengangkat air dari rumahnya, sementara disungai mereka bebas menggunakan air.

Jamban cemplung yang disediakan pemerintah memang tidak memiliki sarana air bersih, sehingga masyarakat tidak tertarik untuk menggunakan jamban tersebut.Masyarakat yang hendak buang air besar mau tidak mau harus membawa air penggelontor dari rumah untuk membasuh tinja setelah BAB tetapi tidak dapat digunakan untuk membersihkan lantai sekitas jamban yang kotor dan tidak terdapat alat pembersih jamban.Karena jamban yang digunakan adalah jamban cemplung, maka tidak ada masyarakat yang bertanggung jawab untuk menjaga kebersihan jamban tersebut.

Ketidaktahuan masyarakat akan pentingnya memiliki jamban belum disadari oleh sebagian besar masyarakat di Desa Sisumut Kecamatan Kota Pinang Kabupaten Labuhan Batu Selatan. Padahal dengan adanya jamban maka kebersihan lingkungan akan lebih terjaga sehingga meningkatkan kualitas kesehatan masyarakat. Selain itu dengan adanya penggunaan jamban maka akan menambah nilai estetika dari lingkungan itu sendiri. Hal ini seperti yang utarakan Soemardji dengan jamban, maka tinja yang dikeluarkan oleh manusia tidak menimbulkan bau, pandangan yang tidak sedap dan mencegah kemungkinan terjadi bahaya terhadap kesehatan dan bahaya penyebaranpenyakit akibat tinja. ${ }^{8}$

Menurut asumsi peneliti, terdapat banyak hal yang melatarbelakangi responden dalam memutuskan untuk BAB dijamban atau tidak.Sebagaian besar responden Desa Si sumut kecamatan Kota Pinang Kabupaten Labuhan Batu Selatan tidak memiliki jamban pribadi dan adapun jamban yang dibangun pemerintah tidak memiliki sarana air bersih. Hal tersebut tentunya menjadi sesuatu yang penting untuk diperhatikan karena sangat berkaitan dengan kesehatan masyarakat di Desa Sisumut Kecamatan Kota Pinang Kabupaten Labuhan Batu Selatansebagian besar responden tidak memiliki jamban adalah tidak memiliki cukup dana untuk membuat jamban pribadi atau jamban yang ideal di rumah mereka. Alasan lain yang kerap muncul adalah letak geografis tempat tinggal responden yang dekat dengan sungai. Masyarakat yang belum memiliki jamban bukan semata-mata hanya karena faktor ekonomi, tetapi lebih kepada kurangnya kesadaran masyarakat tentang PHBS.Selain itu faktor lainya adalah ketergantungan masyarakat kepada bantuan pemerintah dalam hal pembangunan jamban. Hal tersebut tentunya akan lebih efektif apabila pemberian bantuan tersebut disertai dengan sosialisasi yang bersifat edukatif berkaitan dengan pemanfaatan jamban.

Pendidikan merupakan pembelajaran pengetahuan, keterampilan, dan kebiasaan sekelompok orang yang diturunkan dari satu generasi ke generasi berikutnya melalui pengajaran, pelatihan, atau penelitian.Pada penelitian ini, pendidikan dikategorikan kedalam 2 jenis kategori yaitu tinggi dan rendah.Kategori rendah yaitu tingkat pendidikan kepala keluarga yang tidak bersekolah, atau bersekolah hanya 
sampai jenjang SD atau jenjang SMP. Sedangkan, kategori tinggi yaitu tingkat pendidikan kepala keluarga sampai tingkat SMA dan sarjana.

Berdasarkan hasil penelitian diketahui bahwa dari dari 37 responden yang diteliti, sebagian besar responden memiliki sikap negtif sebanyak 26 (70,27\%) responden. Dari 26 $(70,27 \%)$ responden tersebut, ada sebanyak 7 $(18,92 \%)$ responden memiliki sikap negatif dan memanfaatkan jamban cemplung, dan sebanyak $19(51,35 \%)$ responden memiliki sikap negatif dan tidak memanfaatkan jamban cemplung. Berdasarkan hasil perhitungan uji statistik diperoleh nilai $p$ significancy yaitu $0,000<0,05$, sehingga dapat disimpulkan bahwa ada pengaruh sikap terhadap penggunaan jamban cemplung di Desa Sisumut Kecamatan Kota Pinang Kabupaten Labuhan Batu Selatan.

Pendidikan merupakan salah satu unsur yang menjadi pertimbangan dalam melaksanakan tugas dan tanggung jawab, oleh karena dapat memberikan suatu informasi mengenai tingkat kemampuan dan kompetensi seseorang. Pendidikan berfungsi dalam mengembangkan kemampuan dan meningkatkan kualitas individu, di dalam proses belajar akan terjadi perubahan ke arah yang lebih baik, lebih dewasa dan lebih matang dalam diri individu.(7)

Pendidikan kepala keluarga yang rendah menyebabkan banyak kepala keluarga yang tidak mengetahui fungsi dari memanfaatkan jamban. Sehingga menurut penelitian Widowati, Nilansari Nur menyebutkan masyarakat yang berpendidikan dasar / rendah yang tidak memiliki jamban dan yang sudah memiliki jamban perlu dilakukan suatu pendekatan dan penerapan pola hidup bersih dan sehat dengan cara door to door dari petugas kesehatan untuk memberikan pengertian terkait perilaku BABS, pemanfaatan jamban serta menjaga kondisi rumah untuk tetap bersih dan sehat ${ }^{8}$

Sesuai dengan pendapat Soekidjo yang menyebutkan pendidikan merupakan faktor yang berpengaruh dalam membentuk pengetahuan, sikap, persepsi, kepercayaan dan penialaian seseorang terhadap kesehatan, sehingga dapat disimpulkan bahwa semakin tinggi pendidikan seseorang makan semakin tinggi pula kesadarannya untuk tetap menjaga kebersihan dan lingkungannya ${ }^{7}$

Tingkat pendidikan merupakan jenjang pendidikan terakhir yang ditempuh seseorang tingkat pendidikan merupakan suatu wahana untuk mendasari seseorang berprilaku secara ilmiah. Tingkat pendidikan yang rendah akan susah mencerna pesan atau informasi yang disampaikan. Pendidikan diperoleh melalui proses belajar yang khusus diselenggarakan dalam waktu tertentu, tempat tertentu dan kurikulum tertentu, namun dapat diperoleh dari bimbingan yang diselenggarakan sewaktu-waktu dengan maksud mempertinggi kemampuan atau ketrampilan khusus. Dalam garis besar ada tiga tingkatan pendidikan yaitu pendidikan rendah, pendidikan menengah, dan tinggi.Masingmasing tingkat pendidikan tersebut memberikan tingkat pengetahuan tertentu yang sesuai dengan tingkat pendidikan.

Pendidikan tentang menggunakan jamban yang baik dan sehat merupakan suatu proses mengubah kepribadian, sikap, dan pengertian tentang jamban yang sehat sehingga tercipta pola kebudayaan dalam menggunakan jamban secara baik dan benar tanpa ada paksaan dari pihak manapun. ${ }^{7}$

Berpedoman pada tujuan pendidikan diperkirakan bahwa semakin meningkatnya pendidikan yang dicapai sebagian besar penduduk, semakin membantu kemudahan pembinaan dan akan memudahkan masyarakat memahami tentang pentingnya menggunakan jamban. Dengan demikian pendidikan pada dasarnya merupakan usaha dan tindakan yang bertujuan untuk mengubah pengetahuan, sikap dan keterampilan manusia.Tingkat pendidikan yang cukup merupakan dasar dalam pengembangan daya nalar serta sarana untuk menerima pengetahuan.

Kemampuan menerima seseorang akan lebih cepat jika orang tersebut memiliki latar belakang pendidikan yang cukup. Pengertian tersebut menggambarkan pendidikan bukan hanya mempersiapkan masa depan agar lebih cerah saja, melainkan untuk membantu setiap individu mengembangkan faktor psikisnya menuju tingkat kedewasaan.

Sejak dini pendidikan harus sudah diberlakukan pada setiap individu agar menjadikan manusia tersebut berkualitas dan tidak menimbulkan dampak yang negatif pada dirinya sendiri atau orang lain khususnya dalam pemanfaatan jamban cemplung, oleh sebab itu diasumsikan bahwa semakin tinggi tingkat pendidikan seseorang, maka semakin mampu dia mengetahui, memahami ataupun menganalisis tentang hidup bersih dan sehat,, sebaliknya semakin rendah tingkat pendidikan yang dia miliki maka semakin rendah atau tidak tahu pula dia mencerna apa yang menjadi isi pesan dari informasi khususnya dalam hal 
penggunaan maupun pemanfaatan jamban

Berdasarkan hasil penelitian diketahui bahwa dari 37 responden yang diteliti, sebagian besar responden tersedia akses sebanyak 19 $(51,35 \%)$ responden. Dari 19 (51,35\%) responden tersebut, ada sebanyak $3(8,11 \%)$ responden tersedia akses dan memanfaatkan jamban cemplung, dan sebanyak $16(43,24 \%)$ responden tersedia akses dan tidak memanfaatkan jamban cemplung. Berdasarkan hasil perhitungan uji statistik diperoleh nilai $p$ significancy yaitu $0,000<0,05$, sehingga dapat disimpulkan bahwa ada pengaruh ketersediaan akses terhadap penggunaan jamban cemplung di Desa Sisumut Kecamatan Kota Pinang Kabupaten Labuhan Batu Selatan.

Terwujudnya sikap menjadi suatu tindakan, menurut Soekidjo diperlukan suatu kondisi yang memungkinkan seseorang dapat menerapkan apa yang sudah ia ketahui. Artinya pengetahuan atau sikap yang baik belum tentu mewujudkan suatu tindakan yang baik. Karena perubahan sikap ke arah yang lebih baik akan mempengaruhi terjadinya peran serta masyarakat yang merupakan modal utama keberhasilan program kesehatan. ${ }^{7}$

Menurut Green sikap merupakan faktor predisposisi yang akan membentuk suatu tindakan atau perilaku. Ketidaksesuaian perilaku seseorang dengan sikapnya akan menimbulkan masalah psikologis bagi individu -individu yang bersangkutan, sehingga mereka akan berusaha merubah sikap atau perilakunya.

Pemberian intervensi ini harus benar-benar dilakukan dalam rangka pencapaian derajat kesehatan masyarakat di Desa Sisumut Kecamatan Kota Pinang Kabupaten Labuhan Batu Selatan yang mengarah kepada masyarakat yang berperilaku hidup sehat dalam menunjang kegiatan pembangunan kesehatan berwawasan lingkungan yang berada diwilayah tersebut

Dari hasil penelitian diatas, peneliti berasumsi sikap masyarakat di Desa Sisumut Kecamatan Kota Pinang Kabupaten Labuhan Batu Selatan rata-rata buruk dalam pemanfaatan jamban yang dapat dilihat. Maka dari itu perlu adanya upaya peningkatan sikap ke arah yang benar. Dalam mengarahkan sikap yang benar, perlu dilakukan contoh bagaimana menggunakan jamban yang benar, sehingga masyarakat akan merespon dengan baik. Hal ini dapat dimulai dari lingkup terkecil yaitu keluarga, kemudian dilanjutkan oleh pemerintah serta petugas kesehatan melalui program-program penyuluhan dengan melibatkan masyarakat sebagai objek sasaran sebuah program mulai dari penyusunan hingga pelaksanaan program.

\section{KESIMPULAN DAN SARAN}

Berdasarkan hasil penelitian, dapat disimpulkan bahwa pengetahuan $(p=0,000)$, sikap $(p=0,000)$ dan ketersediaan akses $(p=0,000)$ berpengaruh terhadap penggunaan jamban cemplung di Desa Sisumut Kecamatan Kota Pinang Kabupaten Labuhan Batu Selatan, sehingga adapun saran dalam penelitian ini diharapkan agar membuat program penyuluhan tentang pemanfaatan jamban cemplung kepada masyarakat.

\section{REFERENSI}

1. Kementerian Kesehatan. Pedoman Umum Program Indonesia Sehat dengan Pendekatan Keluarga. Kementerian Kesehatan, Jakarta; 2018. 78 p.

2. World Health Organization, Sanitation and Environment health: 2018.

3. Sanitasi Bersih Seksi Penyehatan Lingkungan Dinas Kesehatan Provinsi Sumatera Utara; 2019.

4. Dinas Kesehatan Kabupaten Labuhan Batu Selatan. Profil Kesehatan Kabupaten Labuhan Batu Selatan Tahun 2019.

5. Lawrence G. Health Education A Diagnosis Approach, The John Hopkins University: Mayfield Publishing Co; 2011.

6. Chandra, B. Pengantar Kesehatan Lingkungan. Jakarta; 2013.

7. Kholid, Ahmad. Promosi Kesehatan dengan pendekatan teori prilaku, media, dan aplikasinya. Perpustakaan Nasional: Katalog Dalam Terbitan (KDT). Jakarata : Rajawali Pers;2012.

8. Kurniawati, Linda Destiya; Windraswara, Rudatin. Faktor-Faktor yang Berpengaruh terhadap Perilaku Kepala Keluarga dalam Pemanfaatan Jamban di Pemukiman Kampung Nelayan Tambaklorok Semarang. Public Health Perspective Journal. 2017; 2.1. 